\title{
Multiple stress responses in Streptococcus mutans and the induction of general and stress-specific proteins
}

\author{
Gunnel Svensäter, ${ }^{1}$ Bodil Sjögreen ${ }^{1}$ and Ian R. Hamilton ${ }^{2}$
}

Author for correspondence: Ian R. Hamilton. Tel: +1 204789 3615. Fax: +1 2047893948. e-mail: ihamilt@cc.umanitoba.ca

1 Department of Oral Microbiology, Malmö University, S-21421 Malmö, Sweden

2 Department of Oral Biology, University of Manitoba, 780 Bannatyne Ave, Winnipeg, Manitoba, Canada R3E 0W2
The authors have previously demonstrated that Streptococcus mutans shows an exponential-phase acid-tolerance response following an acid shock from pH 7.5 to 5.5 that enhances survival at pH 3.0. In this study the response of $S$. mutans $\mathrm{H} 7$ to acid shock was compared with the responses generated by salt, heat, oxidation and starvation. Prior induction of the acid-tolerance response did not cross-protect the cells from a subsequent challenge by the other stresses; however, prior adaptation to the other stresses, except heat $\left(42{ }^{\circ} \mathrm{C}\right)$, protected the cells during a subsequent acid challenge at pH 3.5. Starvation by fivefold dilution of the basal medium (BM) plus fivefold reduction of its glucose content increased the numbers of survivors 12-fold, whereas elimination of glucose from fivefold-diluted BM led to a sevenfold enhancement compared to the control cells; this indicated a relationship between the acid and starvation responses. The stress responses were further characterized by comparing the 2D electrophoretic protein profiles of exponential-phase cells subjected to the various stress conditions. Cells were grown to exponential phase at pH $7.5\left(37^{\circ} \mathrm{C}\right)$ and then incubated for $30 \mathrm{~min}$ under the various stress conditions in the presence of ${ }^{14} \mathrm{C}$-labelled amino acids followed by cell extraction, protein separation by 2D gel electrophoresis and image analysis of the resulting autoradiograms. Using consistent twofold or greater changes in IOD \% as a measure, oxidative stress resulted in the upregulation of 69 proteins, 15 of which were oxidation-specific, and in the downregulation of $\mathbf{2 4}$ proteins, when compared to the control cells. An acid shock from pH 7.5 to 5.5 enhanced synthesis of 64 proteins, 25 of them acidspecific, while 49 proteins exhibited diminished synthesis. The dilution of BM resulted in the increased formation of 58 proteins, with 11 starvation-specific proteins and 20 showing decreased synthesis. Some 52 and 40 proteins were enhanced by salt and heat stress, with 10 and 6 of these proteins, respectively, specific to the stress. The synthesis of a significant number of proteins was increased by more than one, but not all stress conditions; six proteins were enhanced by all five stress conditions and could be classified as general stress proteins. Clearly, the response of $S$. mutans to adverse environmental conditons results in complex and diverse alterations in protein synthesis to further cell survival.

Keywords: stress, stress proteins, cross-protection, Streptococcus mutans

\section{INTRODUCTION}

Bacteria in the biofilms on teeth (dental plaque) are subjected to cycles of acid shock resulting from the rapid formation of acid end-products generated during the metabolism of dietary carbohydrate by the acidogenic oral microflora. The rate of acid formation in human plaque, as measured by in vivo $\mathrm{pH}$ telemetry, shows that

Abbreviations: 2DE, two-dimensional polyacrylamide electrophoresis; BM, basal medium (the salts, vitamins and amino acids of MM4 medium); IOD, integrated optical density. 
the intake of carbohydrates can lower the plaque $\mathrm{pH}$ from 7 to 4 in as little as 3 min depending on the age of the biofilm and the concentration of the carbohydrate (Imfeld \& Lutz, 1980; Yamada et al., 1980; Jensen et al., 1982). Furthermore, the frequent ingestion of sugar is associated with a lowering of the 'resting' plaque $\mathrm{pH}$ and an increase in dental caries. Early studies (Stephan, 1944) demonstrated that the microflora associated with high caries activity was not only capable of rapid plaque acidification following the ingestion of sugar, but was also tolerant to the low resting plaque $\mathrm{pH}$. Thus, it is not surprising that acid tolerance is an important 'virulence' property associated with cariogenic bacteria, such as Streptococcus mutans, Lactobacillus species and certain non-mutans streptococci (Bowden, 1991; Sansone et al., 1993; van Houte et al., 1996).

During short-term exposure to acidic environments, $S$. mutans maintains $\mathrm{pH}$ homeostasis by proton extrusion from the cell via the membrane-associated, protontranslocating ATPase $\left(\mathrm{H}^{+} /\right.$ATPase) (Bender et al., 1986; Hamilton \& Buckley, 1991), and by acid endproduct efflux (Carlsson \& Hamilton, 1996; Dashper \& Reynolds, 1996). Sustained growth at pH 5.5, however, results in increased $\mathrm{H}^{+}$/ATPase (Bender et al., 1986; Belli \& Marquis, 1991; Hamilton \& Buckley, 1991) and glycolytic activity (Hamilton \& Ellwood, 1978), which is accompanied by a lowering of the $\mathrm{pH}$ optimum for sugar transport and glycolysis (Hamilton \& Buckley, 1991), and increased lactic acid formation (Hamilton, 1987). Moreover, unlike the enteric bacteria (Padan et al., 1981), S. mutans does not maintain a constant intracellular $\mathrm{pH}$ during a falling external $\mathrm{pH}$, but exhibits a relatively consistent transmembrane $\mathrm{pH}$ gradient $(\sim 1.0$ unit) sustained by a carbon source (Hamilton, 1986, 1990; Hamilton \& Buckley, 1991; Dashper \& Reynolds, 1992). Thus, growth at pH 5.5 results in the induction of metabolic changes that permit the organism to maintain the transmembrane $\mathrm{pH}$ gradient at lower $\mathrm{pH}$ values (Hamilton, 1986; Hamilton \& Buckley, 1991; Dashper \& Reynolds, 1992)

Recently, we have demonstrated that exposure of exponential-phase cells of $S$. mutans LT11 to a $\mathrm{pH}$ change from 7.5 to 5.5 resulted in the induction of an acid-tolerance response over a $2 \mathrm{~h}$ period that increased cell survival at $\mathrm{pH} 3.0$ (Svensäter et al., 1997). The $\mathrm{pH}$ change resulted in significant alterations in protein synthesis : pulsing the cells with ${ }^{14} \mathrm{C}$-labelled amino acids at intervals during the $2 \mathrm{~h}$ period, followed by extraction and one-dimensional polyacrylamide gel electrophoresis, revealed the upregulation of 36 proteins, with 25 of these being acid-responsive proteins appearing within the first $30 \mathrm{~min}$ of the $\mathrm{pH}$ change (Hamilton $\&$ Svensäter, 1998). The synthesis of all but two of the proteins was transient during the $2 \mathrm{~h}$ adaptation period. The identity of the proteins is not known, but molecular mass comparisons suggested that both acid-specific proteins (i.e. components of the $\mathrm{H}^{+} /$ATPase) and general stress proteins (i.e. heat-shock proteins) are present in extracts of the acid-induced cells.
The coordinated induction of general and specific proteins by a variety of stress conditions is relatively well characterized in Escherichia coli and Bacillus subtilis, particularly with respect to the heat-shock proteins (Hecker et al., 1996; Yura et al., 1993). A number of stress responses have been identified in Lactococcus lactis and it is clear that there is an overlap in the protective mechanisms induced by various conditions (Rallu et al., 1996). Carbohydrate-starved stationary-phase cells of L. lactis IL1403 exhibited increased resistance to acid, heat, ethanol and osmotic and oxidative stress (Hartke et al., 1994), while UVirradiated cells of the same strain showed enhanced survival against acid, ethanol, hydrogen peroxide and heat (Hartke et al., 1995). An overlap between the heatshock and salt responses has also been reported for $L$. lactis MG1363, with all salt-stress-induced proteins also subject to induction by heat stress (Kilstrup et al., 1997).

In the current study, we were interested in the relationship between the acid-tolerance response generated by $S$. mutans and the response of the organism to other adverse conditions, such as, salt, heat, starvation and oxidative stress. Two approachs were taken: an examination of whether reciprocal cross-protection exists between these various stresses, and a comparison of the stress-induced proteins formed under the various conditions. For the latter study, cells were exposed to stress in the presence of ${ }^{14} \mathrm{C}$-labelled amino acids and the protein extracts subjected to two-dimensional polyacrylamide electrophoresis (2DE) and autoradiography. Comparative analysis revealed three groups of proteins: general stress proteins enhanced under all conditions, those specific to the particular stress, and those induced by more than one, but not all, stress conditions.

\section{METHODS}

Bacterial strain and media. S. mutans $\mathrm{H} 7$ was isolated from an approximal caries lesion at $\mathrm{pH} 5 \cdot 0$ and maintained anaerobically in complex liquid medium containing (per litre): tryptone $(10 \mathrm{~g})$, yeast extract $(5 \mathrm{~g})$ and $20 \mathrm{mM}$ glucose buffered with $40 \mathrm{mM}$ phosphate/citrate buffer as previously described (Svensäter et al., 1997). Comparative studies on crossprotection and ${ }^{14} \mathrm{C}$-labelled amino acid incorporation into cellular protein during stress were carried out with cells growing anaerobically in a minimal medium (MM4) containing six amino acids (glutamate, serine, cysteine, valine, leucine, asparagine) to which was added various amount of glucose (Hamilton \& Svensäter, 1998). In the context of this paper, the basal medium (BM) refers to the salts, vitamins and amino acids of MM4 medium.

Adaptation conditions. Cells were grown to mid-exponential phase in MM4 with $20 \mathrm{mM}$ glucose at $\mathrm{pH} 7 \cdot 5$; the cells were rapidly concentrated by centrifugation $(5000 \mathrm{~g}$ for $5 \mathrm{~min})$ and washed in sterile saline $(0 \cdot 16 \mathrm{M} \mathrm{NaCl})$, and aliquots $\left(\sim 10^{8}\right.$ cells $\mathrm{ml}^{-1}$ ) were inoculated into $5 \mathrm{ml}$ fresh MM4 medium with $20 \mathrm{mM}$ glucose buffered with $40 \mathrm{mM}$ phosphate/citrate buffer under the following conditions: (a) pH 5.5, (b) $42{ }^{\circ} \mathrm{C}$,

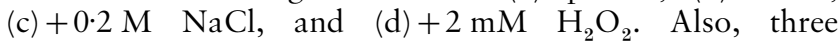
'starvation' conditions were tested: S-1, 20\% BM+20 mM 
glucose; S-2, $20 \% \mathrm{BM}+4 \mathrm{mM}$ glucose; and S-3, 20\% BM without glucose. Both unadapted control and test cells were incubated at $\mathrm{pH} 7.5$ and $37^{\circ} \mathrm{C}$, except (a) and (b), respectively. Unless otherwise specified, incubation was for $2 \mathrm{~h}$ and the $\mathrm{pH}$ of the suspensions did not change by more than $\pm 0.2 \mathrm{pH}$ units.

Challenge conditions. Adapted and unadapted exponentialphase cells were harvested and rapidly washed in sterile saline by centrifugation $(5000 \mathrm{~g}$ for $5 \mathrm{~min}$ ), then added at a constant cell concentration $\left(\sim 10^{8}\right.$ cells $\left.\mathrm{ml}^{-1}\right)$ to $5 \mathrm{ml}$ fresh MM4 medium and incubated for $2 \mathrm{~h}$ under the following conditions : (a) $\mathrm{pH} 3 \cdot 5$, (b) $50{ }^{\circ} \mathrm{C}$, (c) $+2 \mathrm{M} \mathrm{NaCl}$, (d) $+15 \mathrm{mM} \mathrm{H}_{2} \mathrm{O}_{2}$, and the three 'starvation' conditions listed above. Both unadapted control and test cells were incubated at $\mathrm{pH} 7 \cdot 5$ and $37^{\circ} \mathrm{C}$, except (a) and (b), respectively. Incubation was for $2 \mathrm{~h}$ and the $\mathrm{pH}$ of the suspensions did not change by more than $\pm 0 \cdot 2 \mathrm{pH}$ units.

Cross-protection protocols. Cross-over experiments were undertaken to determine whether (i) the prior induction of the acid-tolerance response by exponential-phase cells of $S$. mutans $\mathrm{H} 7$, achieved by incubating $\mathrm{pH} 7 \cdot 5$-grown cells at $\mathrm{pH}$ 5.5 for $2 \mathrm{~h}$, would affect survival under challenge with the other stresses, and (ii) the prior adaptation to the other stresses would affect the ability of the cells to survive a $2 \mathrm{~h}$ exposure in MM4 medium buffered at $\mathrm{pH} 3 \cdot 5$. Following exposure to the stress, cell samples were diluted and plated on trypticase agar $\left(\mathrm{g} \mathrm{l}^{-1}\right.$ : trypticase, 10 ; yeast extract, $2 ; \mathrm{Na}_{2} \mathrm{CO}_{3}, 2 ; \mathrm{NaCl}, 5$; glucose, 2; agar, 10; buffered at $\mathrm{pH} 7 \cdot 2$ ). The percentage of cell survivors was calculated by comparison with viable cell counts of the culture suspension just prior to challenge. The data shown are the means of at least three determinations \pm standard error.

${ }^{14} \mathrm{C}$ labelling of stress proteins. The assays for the induction of the various stress responses followed the 'adaptation' conditions above with the exception that only starvation condition S-1 (20\% BM $+20 \mathrm{mM}$ glucose) was tested. Cells were grown to mid-exponential phase $\left(\mathrm{OD}_{600} 0 \cdot 6\right.$; the stationary phase $\mathrm{OD}_{600}$ was 1.2 ) in MM4 with $20 \mathrm{mM}$ glucose at $\mathrm{pH} 7 \cdot 5$, centrifuged and resuspended in glucose- and buffer-free MM4. The cell suspension was added to the different adaptation media to give a concentration of $5 \times 10^{8}$ cells $\mathrm{ml}^{-1}$ in a total volume of $2.5 \mathrm{ml}$. Immediately after addition of the cell suspension, $50 \mu \mathrm{Ci}(1850 \mathrm{kBq})$ of a ${ }^{14} \mathrm{C}$-labelled amino acid mixture (Amersham) was added to the adaptation medium and incubation carried out for $30 \mathrm{~min}$. Then $1 \mathrm{mg}$ chloramphenicol was added to stop protein synthesis, and the cell suspension was rapidly cooled in ice. The suspensions were centrifuged at $15000 \mathrm{~g}$ for $10 \mathrm{~min}$; the cells were washed twice and resuspended in $0.5 \mathrm{ml} 10 \mathrm{mM}$ Tris/ $\mathrm{HCl}, \mathrm{pH} 6.8$, with $1 \mathrm{mM}$ EDTA and $5 \mathrm{mM} \mathrm{MgSO}$. The cells were stored at $-80^{\circ} \mathrm{C}$ until used. The frozen cells were thawed, centrifuged and resuspended in $0.5 \mathrm{ml}$ lysis buffer containing $8 \mathrm{M}$ urea, $2 \%$ (v/v) Nonidet P-40, $62 \mathrm{mM}$ DTT and 2\% (v/v) Pharmalyte, $\mathrm{pH}$ range 4-7 (Pharmacia Amersham Biotech). Proteins were extracted by vortexing $0.5 \mathrm{ml}$ cell samples in lysis buffer with $0.2 \mathrm{~mm}$ glass beads $(1: 1, \mathrm{v} / \mathrm{v})$ six times for $30 \mathrm{~s}$ with cooling between vortexing. The samples were centrifuged at $2500 \mathrm{~g}$ for $5 \mathrm{~min}$ to remove the beads. The bead-free supernatant was centrifuged at $15000 \mathrm{~g}$ for $15 \mathrm{~min}$ at $4{ }^{\circ} \mathrm{C}$ and the resultant cell-free extracts were frozen until used.

2DE. The first-dimension isoelectric focusing was performed using the Multiphor II horizontal electrophoresis apparatus connected to an EPS 3500 XL Power Supply and Multitemp II thermostatic circulator (Amersham Pharmacia Biotech). Immobiline DryStrip linear immobilized $\mathrm{pH}$ gradient (IPG) gel strips $(18 \mathrm{~cm})$ with a $\mathrm{pH}$ range of $4-7$ were rehydrated in
$330 \mu \mathrm{l}$ sample buffer (SB) containing $8 \mathrm{M}$ urea, 2\% (v/v) Nonidet P-40, $10 \mathrm{mM}$ DTT and 2\% (v/v) Pharmalyte, $\mathrm{pH}$ range 4-7 (Pharmacia Amersham Biotech). Rehydration was carried out overnight at room temperature in a reswelling casette with strips covered with silicone oil to avoid evaporation. The reswollen strips were rinsed with deionized water and carefully blotted with wet filter paper to remove excess rehydration solution. The strips were placed into the DryStrip kit on the Multiphor II and electrode strips loaded with $300 \mu$ deionized water. The ${ }^{14} \mathrm{C}$-labelled samples were diluted in the above SB buffer and applied in sample cups under silicone oil at the anodic end of the gel strip. The same amount of sample radioactivity (500000 c.p.m.) was loaded on each gel, corresponding to $30-60 \mu \mathrm{g}$ protein. The proteins were focused overnight at $15^{\circ} \mathrm{C}$ under a protective layer of silicone oil using $150 \mathrm{~V}$ for $1 \mathrm{~h}, 300 \mathrm{~V}$ for $3 \mathrm{~h}, 600 \mathrm{~V}$ for $3 \mathrm{~h}$, $1200 \mathrm{~V}$ for $12 \mathrm{~h}$ and $3500 \mathrm{~V}$ for $18 \mathrm{~h}$. After focusing, the IPG gel strips were immediately frozen between plastic films at $-80{ }^{\circ} \mathrm{C}$.

The second-dimension electrophoresis was carried out essentially as described by Laemmli (1970) with 12-14\% polyacrylamide gradient gels $(185 \times 200 \times 1.0 \mathrm{~mm})$. Immediately before SDS-PAGE, the IPG gel strips were shaken gently in $10 \mathrm{ml} 50 \mathrm{mM}$ Tris $/ \mathrm{HCl}(\mathrm{pH} 6 \cdot 8), 2 \%$ (w/v) SDS and $26 \%$ $(\mathrm{v} / \mathrm{v})$ glycerol for $2 \times 15 \mathrm{~min}$. DTT $(25 \mathrm{mg})$ was added to the first equilibration solution, and iodoacetamide $(450 \mathrm{mg})$ and bromophenol blue to the second. The IPG strips were quickly loaded on top of the gel and overlaid with $1 \%(\mathrm{w} / \mathrm{v})$ molten agarose (Bio-Rad). The separation was performed at $10^{\circ} \mathrm{C}$ overnight at $40 \mathrm{~mA}$ until the bromophenol blue dye front reached the bottom of the gels. The gels were fixed in $40 \%$ methanol and $7 \cdot 5 \%$ acetic acid for $45 \mathrm{~min}$, vacuum-dried at $60{ }^{\circ} \mathrm{C}$ for $3 \mathrm{~h}$ and then subjected to autoradiography.

The apparent isolelectric point and molecular mass of protein spots were determined relative to those of known protein standards. The pI standards were purchased from Amersham Pharmacia Biotech (carbamylated carbonic anhydrase and glyceraldehyde-3-phosphate dehydrogenase) and co-electrophoresed with bacterial proteins in some of the first-dimension gels. The gels containing pI standards were silver stained according to the procedure recommended by the manufacturer before autoradiography. ${ }^{14} \mathrm{C}$-labelled molecular mass standards were obtained from Amersham (myosin, $220 \mathrm{kDa}$; phosphorylase b, 97.4 kDa; bovine serum albumin, $66 \mathrm{kDa}$; ovalbumin, $46 \mathrm{kDa}$; carbonic anhydrase, $30 \mathrm{kDa}$; trypsin inhibitor, $21.5 \mathrm{kDa}$; and lysozyme, $14.3 \mathrm{kDa}$ ) and run alongside the second-dimension gels.

Autoradiography. The dried gels were exposed to X-ray film (Hyperfilm b-max, Amersham) for $14 \mathrm{~d}$ and films developed with Kodak D19.

Image analysis. Analysis of digitized images, including spot finding, quantification and matching, was done by using Visage 2-D Electrophoresis Image Analysis software version 4.6 J (Millipore) on a Sun Sparc work station. A reference autoradiogram was chosen and each of the other autoradiograms was matched to it using the BioImage software. The matching procedure consisted of manually selecting 20 tiepoints or 'anchor proteins' on the images and then allowing the machine to automatically match the images. Proteins of known molecular mass were then used as standards to generate $\mathrm{pI}$ and molecular mass values for all the spots in the matched gels by interpolation and extrapolation. The integrated optical density (IOD) of each protein, expressed as a percentage of the total area of blackening of the film attributed to proteins (IOD\%), was calculated along with $\mathrm{pI}$ and molecular mass for each individual spot. Each stress ex- 
periment was carried out at least twice with different cell cultures, and only spots showing a consistent change in IOD \% of at least twofold were taken into account.

Analyses. Protein was determined by the method of Bradford (1976) with the appropriate concentration of lysis buffer in the standards as described by Fey et al. (1997).

\section{RESULTS}

\section{Cross-protection}

An adaptive response to one stress can often lead to cross-protection against another stress (Hartke et al., 1994; Leyer \& Johnson, 1993); hence we were interested

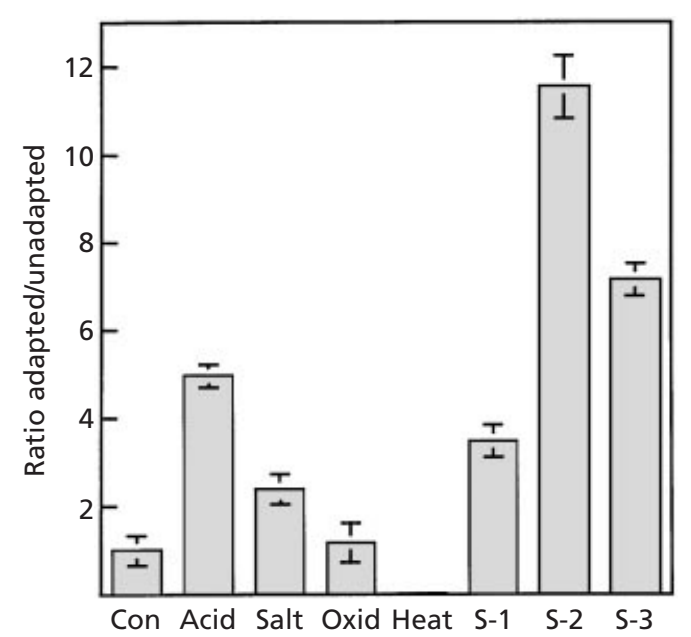

Fig. 1. Effect of prior adaptation to other stresses on the survival of $S$. mutans cells following a subsequent challenge at $\mathrm{pH} 3.5$ for $2 \mathrm{~h}$. With the exception of the control cells (Con), maintained at $\mathrm{pH} 7.5$ in $100 \% \mathrm{BM}+20 \mathrm{mM}$ glucose, cells were exposed to the other stresses for $2 \mathrm{~h}$ prior to the acid challenge. Stress conditions: Acid, pH 5.5; Salt, $0.2 \mathrm{M} \mathrm{NaCl}$; Oxid, $2 \mathrm{mM}$ $\mathrm{H}_{2} \mathrm{O}_{2}$; Heat, $42{ }^{\circ} \mathrm{C}$. Starvation conditions: S-1, $20 \% \mathrm{BM}+20 \mathrm{mM}$ glucose; S-2, $20 \% \mathrm{BM}+4 \mathrm{mM}$ glucose; S-3, $20 \% \mathrm{BM}$ without glucose. All incubations except that for the heat stress were at $37^{\circ} \mathrm{C}$. in the relationship of the acid response in $S$. mutans $\mathrm{H} 7$ to other stress responses. We therefore tested whether prior adaptation to acid ( $\mathrm{pH} 7 \cdot 5$ to $5 \cdot 5)$ would affect survival under challenge with other stresses. Incubation of $\mathrm{pH} 7 \cdot 5$-grown exponential-phase cells at $\mathrm{pH} 5.5$ for $2 \mathrm{~h}$ resulted in the expected induction of the exponentialphase acid-tolerance response, with fourfold more survivors at $\mathrm{pH} 3.5$ than for control cells maintained at $\mathrm{pH} 7.5$ (data not shown). However, with exception of heating at $50{ }^{\circ} \mathrm{C}$, which significantly reduced cell numbers at $\mathrm{pH} 3 \cdot 5$, adaptation to acid stress had no significant effect on survival when cells were challenged with $2 \mathrm{M} \mathrm{NaCl}$ or $15 \mathrm{mM} \mathrm{H}_{2} \mathrm{O}_{2}$, or with fivefold diluted $\mathrm{BM}$ with 20, 4 or $0 \mathrm{mM}$ glucose (data not shown).

The converse of the above experiment was also undertaken to determine whether prior adaptation to the other stresses would augment or diminish cell survival after a subsequent $2 \mathrm{~h}$ acid challenge at $\mathrm{pH} 3 \cdot 5$. As seen in Fig. 1, as expected the $\mathrm{pH} 5 \cdot 5$-adapted cells (Acid) showed increased survival over the $\mathrm{pH} 7 \cdot 5$ control cells. Also, prior exposure to the other stresses tested, except a temperature increase to $42{ }^{\circ} \mathrm{C}$ (Heat) and the addition of $2 \mathrm{mM} \mathrm{H}_{2} \mathrm{O}_{2}$ (Oxid), stimulated survival at $\mathrm{pH} 3.5$ compared to the control cells. Particularly noticeable was the effect of starvation conditions with cells preincubated in $20 \%$ BM containing $4 \mathrm{mM}$ glucose (S-2) showing a 12-fold stimulation of survival. Even cells incubated in $20 \%$ BM without glucose (S-3) showed a sevenfold increase in survivors over the control cells incubated in $100 \% \mathrm{BM}$ with $20 \mathrm{mM}$ glucose (Con). This demonstrates a clear relationship between starvation and acid tolerance.

\section{DE analysis}

The stress responses in S. mutans $\mathrm{H} 7$ were further characterized by comparing the expression of proteins in exponential-phase cells during the initial $30 \mathrm{~min}$ period immediately following the application of stress by acid, salt, $\mathrm{H}_{2} \mathrm{O}_{2}$, heat and a fivefold dilution of $\mathrm{BM}$ (starvation condition S-1). Just prior to the application

Table 1. Analysis of the proteins in the 2DE gels in Fig. 2 enhanced or diminished twofold or more by oxidative, acid, starvation, salt or heat stress

Data from Fig. 2 representing those proteins from two separate experiments whose synthesis was enhanced or diminished at least twofold. Designations (B) to (F) refer to the individual gels in Fig. 2.

\begin{tabular}{|lcrcrr|}
\hline & \multicolumn{7}{c|}{ Stress } \\
\cline { 2 - 6 } & $\begin{array}{c}\text { Oxidation } \\
(\mathbf{B})+\end{array}$ & $\begin{array}{c}\text { Acid } \\
(\mathbf{C})\end{array}$ & $\begin{array}{c}\text { Starvation } \\
(\mathbf{D})\end{array}$ & $\begin{array}{r}\text { Salt } \\
(\mathbf{E})\end{array}$ & $\begin{array}{c}\text { Heat } \\
(\mathbf{F})\end{array}$ \\
\hline Total no. of proteins & 510 & 515 & 510 & 443 & 573 \\
Proteins with enhanced expression & 69 & 64 & 58 & 52 & 40 \\
Stress-specific proteins enhanced & 15 & 25 & 11 & 10 & 6 \\
Proteins with diminished expression & 24 & 49 & 20 & 47 & 56 \\
\hline
\end{tabular}



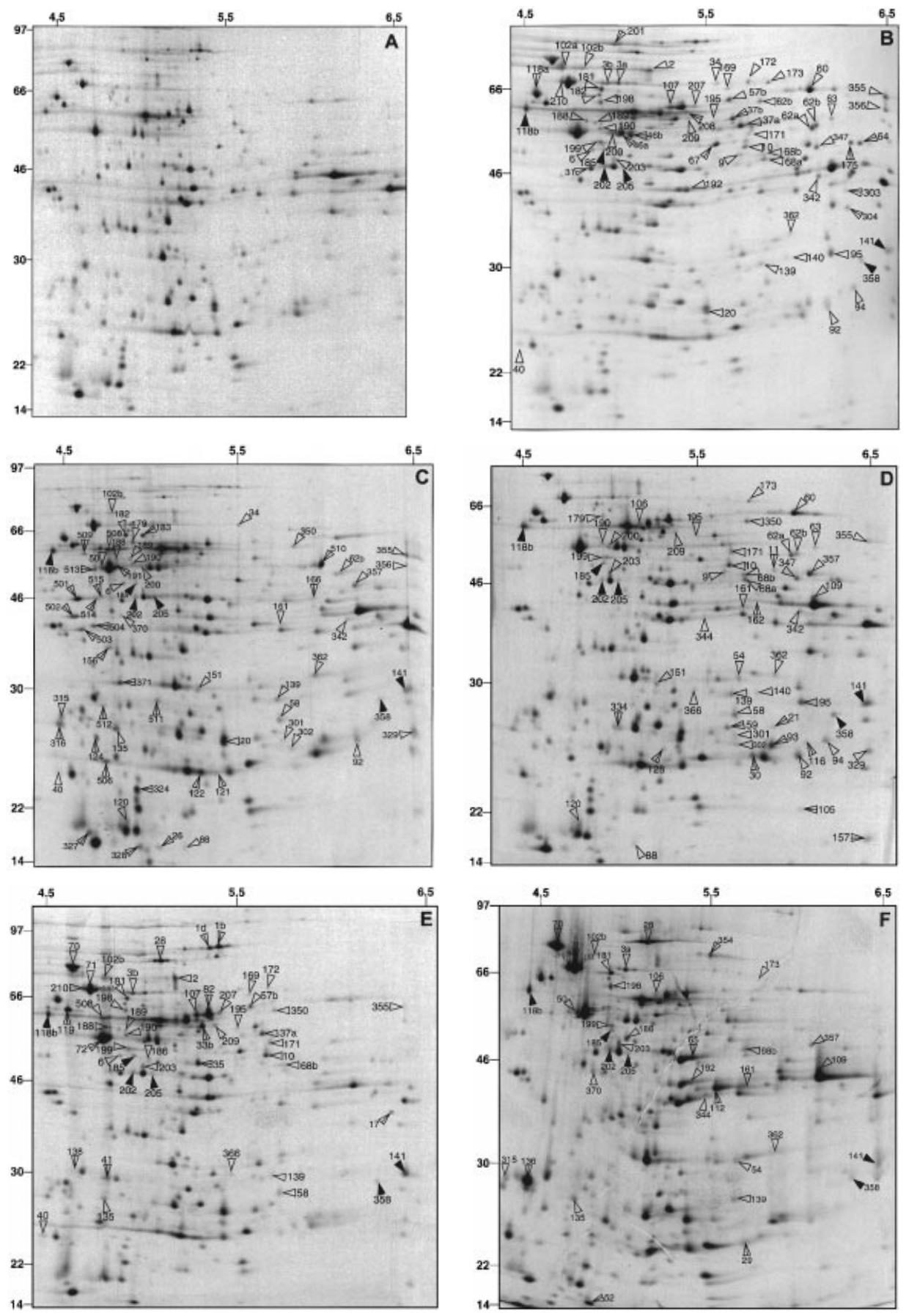

Fig. 2. Autoradiograms of $2 \mathrm{DE}$ protein profiles of exponential-phase cells of $S$. mutans $\mathrm{H} 7$ growing at $\mathrm{pH} 7.5 \mathrm{with} 20 \mathrm{mM}$ glucose and rapidly subjected to various stress conditions for $30 \mathrm{~min}$ in the presence of ${ }^{14} \mathrm{C}$-labelled amino acids followed by extraction, separation by $2 \mathrm{DE}$ and autoradiography. Stress conditions: A, control (cells maintained at $\mathrm{pH} 7.5$ and $\left.37^{\circ} \mathrm{C}\right) ; \mathrm{B}$, oxidative $\left(2 \mathrm{mM} \mathrm{H}_{2} \mathrm{O}_{2}\right) ; \mathrm{C}$, acid (pH 7.5 to 5.5); $\mathrm{D}$, starvation (fivefold dilution of $\left.\mathrm{BM}\right) ; \mathrm{E}$, salt $(0.2 \mathrm{M} \mathrm{NaCl}) ; \mathrm{F}$ heat $\left(37^{\circ} \mathrm{C}\right.$ to $\left.42{ }^{\circ} \mathrm{C}\right)$. All triangles indicate proteins enhanced twofold or more; solid triangles $(\square)$ are general stress proteins and divided triangles $(\leftrightarrow)$ indicate stress-specific proteins. pl scales are given at the top of each panel and molecular mass $(\mathrm{kDa})$ on the left.

of each stress condition, the growth medium was supplemented with ${ }^{14} \mathrm{C}$-labelled amino acids and incubation continued for $30 \mathrm{~min}$ before protein synthesis was arrested with chloramphenicol, and the cells ex- tracted and the proteins separated by $2 \mathrm{DE}$. The resultant gels were then subjected to autoradiography and image analysis. Duplicate experiments were compared and proteins whose expression was enhanced at least two- 
Table 2. Number of proteins in Fig. 2 enhanced twofold or more by one stress condition which are also enhanced by a second condition

Data from Fig. 2 and Table 1 representing those proteins from two separate experiments whose synthesis was enhanced at least twofold. Designations (B) to (F) refer to the individual gels in Fig. 2.

\begin{tabular}{|lcccccc|}
\hline & $\begin{array}{c}\text { Total no. } \\
\text { of proteins }\end{array}$ & $\begin{array}{c}\text { Oxidation } \\
(\mathbf{B})\end{array}$ & $\begin{array}{c}\text { Acid } \\
(\mathbf{C})\end{array}$ & $\begin{array}{c}\text { Starvation } \\
(\mathbf{D})\end{array}$ & $\begin{array}{r}\text { Salt } \\
(\mathrm{E})\end{array}$ & $\begin{array}{c}\text { Heat } \\
(\mathbf{F})\end{array}$ \\
\hline Oxidation & 69 & - & 23 & 32 & 32 & 19 \\
Acid & 64 & 23 & - & 25 & 17 & 16 \\
Starvation & 58 & 32 & 25 & - & 19 & 18 \\
Salt & 52 & 32 & 17 & 19 & - & 21 \\
Heat & 40 & 19 & 16 & 18 & 21 & - \\
\hline
\end{tabular}

fold were identified for each of the conditions. As seen in Fig. 2B and Table 1, exposure of cells to $2 \mathrm{mM} \mathrm{H}_{2} \mathrm{O}_{2}$ resulted in the enhanced synthesis of 69 proteins compared to the control cells maintained at $\mathrm{pH} 7.5$ $\left(37^{\circ} \mathrm{C}\right)$ (Fig. 2A), 15 of which were specific to oxidative stress. Acid stress, induced by a $\mathrm{pH}$ change from $7 \cdot 5$ to $5 \cdot 5$, resulted in the enhanced synthesis of 64 proteins, 25 of which were acid-specific (Fig. 2C), while fivefold dilution of $\mathrm{BM}$ resulted in the enhanced synthesis of 58 proteins, including 11 specific to starvation (Fig. 2D). Salt stress, generated by the addition of $0.2 \mathrm{M} \mathrm{NaCl}$, enhanced the synthesis of 10 salt-specific proteins out of a total of 52 proteins (Fig. 2E), while increasing the temperature to $42^{\circ} \mathrm{C}$ enhanced the synthesis of 40 proteins, 6 of which were heat-specific (Fig. 2F).

Comparative analysis of the 2DE gels in Fig. 2 indicated that the synthesis of six proteins was upregulated by all five stress conditions; these could be considered 'general' stress proteins. In addition, there were a considerable number of proteins (16-32) enhanced by two, three or four of the stress conditions (Table 2). In order to focus on the most significant protein changes, further analysis was restricted to only those proteins demonstrating fivefold or greater increases in labelling under the stress condition when compared to the same spot in the non-stressed control cells using the IOD \% analysis (see Methods) (Table 3). Using this threshold, more proteins (30) were enhanced fivefold or more by acidification than by the other stress conditions, with 19 proteins $(63 \%)$ specific to acid alone (ASPs). Of the ASPs, the most significant increases in synthesis occurred with proteins 510, 501 and 502, which showed 43-, 36and 21-fold increases, respectively, in labelling during the $30 \mathrm{~min}$ incubation. $\mathrm{H}_{2} \mathrm{O}_{2}$-induced oxidative stress generated 25 proteins at this threshold, including 12 specific proteins $(\mathrm{OxSPs})$, with the greatest incorporation of ${ }^{14} \mathrm{C}$ in proteins 200, 106 and 210. Starvation and salt stress each enhanced the synthesis of 13 proteins; however, only one protein was specific to starvation (171) and one to salt (209). The temperature increase to $42{ }^{\circ} \mathrm{C}$ resulted in 15 upregulated proteins, with four being specific to heat (HSPs); the most significant increase (54-fold) was with protein 210. Interestingly, protein 210 was also enhanced by oxidative (25-fold) and salt (13-fold) stress.

Further analysis of the 2DE gels revealed 18 proteins whose expression was reduced fivefold or more by the various stress conditions, with the majority (14) specific to the particular stress condition (Table 4). Eight proteins were downregulated by salt and heat stress, while oxidation, acid and starvation stress resulted in the diminished synthesis of three proteins, two proteins and one protein, respectively. Notable changes were shown by the specifically repressed proteins 43 (HSRP), 83 (OxSRP) and 108 (SaSRP), with reductions of 21-, 43and 29-fold, respectively.

\section{DISCUSSION}

Our previous results with $S$. mutans LT11 demonstrated that an acid shock from $\mathrm{pH} 7 \cdot 5$ to $5 \cdot 5$ induced a response in exponential-phase cells that resulted in enhanced survival following incubation at a $\mathrm{pH}(3 \cdot 0)$ that killed control cells maintained at $\mathrm{pH} 7 \cdot 5$ (Svensäter et al., 1997). This acid-tolerance response required $2 \mathrm{~h}$ to complete. Subsequent pulse-chase experiments with ${ }^{14}$ C-labelled amino acids, followed by one-dimensional polyacrylamide electrophoresis and autoradiography, revealed the enhanced formation of 36 proteins following acidification when compared to control cells maintained at pH 7.5 (Hamilton \& Svensäter, 1998). Some 25 proteins appeared within the first $30 \mathrm{~min}$ and all but two of the 36 proteins were synthesized transiently, a response similar to that seen with Salmonella typhimurium (Foster, 1993). Preliminary experiments employing 2DE with $S$. mutans LT11 indicated that the protein profiles for control and acid-stressed cells were similar to those seen in Fig. 2 for S. mutans H7 in this study (data not shown), suggesting that the ability to give complex inducible responses to various stresses is a common characteristic of this species. S. mutans $\mathrm{H} 7$ was selected for these studies because it was a fresh strain isolated from a caries lesion at low $\mathrm{pH}$ (unpublished 
results) and, unlike $S$. mutans LT11, had no previous history of genetic manipulation (Tao et al., 1993).

In this study, the reproducibility of the gels, as determined by the repeated analysis (more than six times) of control and acid-stressed cell extracts, was substantially improved by the use of the precast Immobiline $\mathrm{pH}$ strips and by making the extraction buffer compatible with that used in the first-dimension isoelectric focusing separation. The gels in Fig. 2 were generated with a $\mathrm{pH}$ range of $4-7$ in the first dimension and routinely resulted in the separation of $420-575$ proteins with the various stress conditions. Preliminary studies with first-dimension separation over the $\mathrm{pH}$ range 6-10 revealed only a total of $15-20$ basic proteins, none of which were enhanced during acid shock from $\mathrm{pH} 7 \cdot 5$ to 5.5. This indicates that the 69 proteins enhanced twofold or more by acid in Fig. 2 constitute the major acidresponsive proteins in the organism. Although the cell extracts from the other stress conditions were not subjected to first-dimension separation in the $\mathrm{pH} 6-10$ range, the relative paucity of basic proteins in the organism suggests that the vast majority were observed in this study.

In examining the protein profiles in Fig. 2, one is struck by relatively few 'general' stress proteins (six) enhanced twofold or more by all five stress conditions, although the number of stress-specific proteins ranged from $15 \%$ to $39 \%$ of the enhanced proteins and a significant number were induced by two to four conditions. Raising the threshold to only those proteins enhanced fivefold or more (Table 3) eliminated $66 \%$ of the proteins in the twofold enhanced group and reduced the general stress proteins from six to two (proteins $118 \mathrm{~b}$ and 141). A higher proportion of stress-specific proteins ( 37 of 67 , or $55 \%$ ) survived this analysis, the highest number being associated with acid (19 ASPs) and oxidative stress (12 OxSPs). Furthermore, analysis of the 18 proteins whose synthesis was diminished fivefold or more (Table 4) revealed that most of these proteins (14) were specific to the stress applied. These experiments permit the analysis of alterations in the relative rate of synthesis of particular proteins compared to all other proteins and do not attempt to assess the absolute synthetic rate of these proteins. Furthermore, we are assuming that this approach identifies proteins (enzymes) whose upregulation is indicative of increased metabolic activity in the cells under the particular stress and which may, therefore, be more important than the downregulated proteins (Bloomberg, 1997). This, of course, may be an incorrect assumption.

Currently, the identity of the various proteins upregulated under the various stress conditions is not known; however, the nature of the stress does point to a number of possible proteins associated with physiological responses. For example, prolonged acidification of $S$. mutans cells results in the increased specific activity of the membrane $\mathrm{F}_{1} \mathrm{H}^{+} /$ATPase involved in proton efflux during $\mathrm{pH}$ homeostasis (Belli \& Marquis, 1991; Hamilton \& Buckley, 1991). It is conceivable that the synthesis of the membrane $\mathrm{F}_{1}$ ATPase subunits, previously isolated by Sutton \& Marquis (1987), could be upregulated during the initial acid-shock period. Examination of Table 3 suggests that the $\alpha$ subunit $(58 \mathrm{kDa})$ might be protein 357 , enhanced 8 -fold, while the $\beta$ subunit $(52 \mathrm{kDa})$ might be protein 503 or protein 504 , upregulated 13- and 8-fold, respectively. The $\gamma$ subunit (41 kDa) could be associated with either protein 135 or protein 511 , while the $\delta(27 \mathrm{kDa})$ and $\varepsilon(18 \mathrm{kDa})$ subunits might be associated with proteins 120 and 88, respectively.

The cross-protection experiments with $S$. mutans $\mathrm{H} 7$ demonstrated that a shift in $\mathrm{pH}$ from 7.5 to 5.5 did not protect cells against challenges by salt, oxidation, heat and starvation. Interestingly, the reverse situation, in which the cells were subjected to a $2 \mathrm{~h}$ adaptation to the five stress conditions followed by exposure to a challenge $\mathrm{pH}$ of 3.5 for $2 \mathrm{~h}$, resulted in varying levels of crossprotection, except for heat shock and oxidative stress (Fig. 1). The other stresses, however, promoted survival at $\mathrm{pH} 3 \cdot 5$, with particularly notable protection (12-fold) afforded by diluting the basal medium (BM) fivefold and decreasing the glucose from 20 to $4 \mathrm{mM}$ (starvation condition S-2). Even in the absence of a carbon source (starvation condition S-3), a sevenfold increase in survivors was observed. Since BM was comprised of salts, vitamins and amino acids, it is likely that, in addition to the carbon source, the concentration of key peptides and/or amino acids may be an important factor in the acid-tolerance response in S. mutans (Gale \& Epps, 1942; Hersh et al., 1996).

The overlap between acid and starvation responses is well known and considerable information is now available on the responses to various nutrients by E. coli (Nyström, 1993; VanBogelen et al., 1990), Sal. typhimurium (Spector \& Foster, 1993), B. subtilis (Bernhardt et al., 1997) and L. lactis (Hartke et al., 1994, 1995, 1996). The acid protection afforded to $S$. mutans by the starvation response (Fig. 1) has particular significance in the dental plaque environment. Depending on the age of plaque biofilm, the ingestion of dietary carbohydrate can result in a rapid reduction in $\mathrm{pH}$ to values near $\mathrm{pH}$ 4 , and this $\mathrm{pH}$ can be sustained for some time at sugar concentrations above $1 \%$ (Yamada et al., 1980). Thus, one can speculate that as the plaque $\mathrm{pH}$ and carbohydrate concentration decrease, the cells receive at least two signals to induce the acid response: one triggered by acid and the other by the concentration of the carbon source. The combined effect would generate a level of acid tolerance greater than that achieved by either signal alone. The response to reductions in the available peptide/amino acid supply is less clear. The reduction in the amino acid pool is probably responsible for the starvation response seen in Fig. 2C since amino acids are known to influence $\mathrm{pH}$ homeostasis (Gale \& Epps, 1942; Hersh et al., 1996). Furthermore, it is not yet known whether carbon and amino acid deprivation induce separate responses, although work with other bacteria suggests that the induction of specific proteins is 
Table 3. Proteins upregulated fivefold or more in exponential-phase cells of $S$. mutans $\mathrm{H} 7$ under conditions of stress

Data obtained from the analysis of Fig. 2 and calculated as the IOD \% of the protein spot under the stress condition vs the same spot in the control.

\begin{tabular}{|c|c|c|c|c|c|c|c|c|}
\hline \multirow[t]{2}{*}{$\begin{array}{l}\text { Protein } \\
\text { ID }\end{array}$} & \multirow{2}{*}{$\begin{array}{l}\text { Mol. } \\
\text { mass } \\
(\mathrm{kDa})\end{array}$} & \multirow[t]{2}{*}{ pI } & \multicolumn{5}{|c|}{$\begin{array}{l}\text { Increase in synthesis under } \\
\text { stress condition* }\end{array}$} & \multirow[t]{2}{*}{$\begin{array}{c}\text { Stress } \\
\text { protein } \dagger\end{array}$} \\
\hline & & & Oxid & Acid & Starved & Salt & Heat & \\
\hline 26 & $15 \cdot 0$ & $5 \cdot 07$ & & 6 & & & & ASP \\
\hline 28 & $82 \cdot 8$ & $5 \cdot 10$ & & & & & 6 & HSP \\
\hline $37 \mathrm{a}$ & $57 \cdot 3$ & $5 \cdot 64$ & 7 & & & & & $\mathrm{OxSP}$ \\
\hline 50 & $55 \cdot 5$ & $4 \cdot 77$ & & 14 & & & 13 & \\
\hline $57 b$ & $65 \cdot 6$ & $5 \cdot 58$ & 8 & & & & & $\mathrm{OxSP}$ \\
\hline 60 & $66 \cdot 5$ & $6 \cdot 02$ & 6 & & & & & $\mathrm{OxSP}$ \\
\hline $62 \mathrm{a}$ & $54 \cdot 6$ & $6 \cdot 04$ & 6 & & & & & $\mathrm{OxSP}$ \\
\hline $62 b$ & $55 \cdot 2$ & $6 \cdot 02$ & 14 & 5 & & & & \\
\hline $68 \mathrm{~b}$ & $49 \cdot 6$ & $5 \cdot 75$ & & & 8 & 5 & & \\
\hline 88 & $15 \cdot 9$ & $5 \cdot 21$ & & 6 & & & & ASP \\
\hline 103 & $69 \cdot 4$ & $4 \cdot 76$ & & & & 21 & 31 & \\
\hline 106 & $62 \cdot 5$ & $5 \cdot 17$ & 28 & & 6 & & 9 & \\
\hline 109 & $45 \cdot 3$ & $6 \cdot 14$ & & & 14 & & 23 & \\
\hline $118 b$ & $60 \cdot 1$ & $4 \cdot 51$ & 16 & 9 & 10 & 9 & 10 & GSP \\
\hline 120 & $19 \cdot 7$ & $4 \cdot 90$ & & 8 & 10 & & & \\
\hline 121 & $21 \cdot 7$ & $5 \cdot 38$ & & 9 & & & & ASP \\
\hline 135 & $26 \cdot 6$ & $4 \cdot 84$ & & 5 & & & & ASP \\
\hline 136 & $27 \cdot 5$ & $4 \cdot 66$ & & & & & 8 & HSP \\
\hline 141 & $29 \cdot 1$ & $6 \cdot 40$ & 10 & 16 & 13 & 17 & 7 & GSP \\
\hline 156 & $34 \cdot 6$ & $4 \cdot 81$ & & 5 & & & & ASP \\
\hline 158 & $50 \cdot 6$ & 5.99 & 6 & & & & & OxSP \\
\hline 161 & $42 \cdot 3$ & $5 \cdot 73$ & & & 6 & & 6 & \\
\hline 171 & $54 \cdot 8$ & $5 \cdot 68$ & & & 10 & & & SSP \\
\hline 172 & $70 \cdot 6$ & $5 \cdot 70$ & 6 & & & & & $\mathrm{OxSP}$ \\
\hline 173 & $70 \cdot 2$ & $5 \cdot 77$ & 6 & & & & & $\mathrm{OxSP}$ \\
\hline 179 & $64 \cdot 5$ & $4 \cdot 94$ & & 6 & & & & ASP \\
\hline 185 & $52 \cdot 2$ & $4 \cdot 95$ & 5 & & & & & OxSP \\
\hline 190 & $56 \cdot 9$ & $4 \cdot 94$ & 7 & 9 & & 7 & & \\
\hline 191 & $55 \cdot 7$ & $4 \cdot 85$ & & 14 & & & & ASP \\
\hline 198 & $65 \cdot 3$ & $4 \cdot 92$ & 14 & & & 7 & 9 & \\
\hline 199 & $53 \cdot 6$ & 4.96 & 12 & & & 6 & & \\
\hline 200 & $56 \cdot 4$ & $4 \cdot 98$ & 29 & 6 & 5 & & & \\
\hline 202 & $48 \cdot 1$ & $4 \cdot 95$ & 12 & 5 & & 6 & 10 & \\
\hline 203 & $50 \cdot 0$ & 4.99 & 6 & & 6 & 7 & 8 & \\
\hline 205 & $48 \cdot 4$ & $5 \cdot 05$ & & 8 & & 5 & & \\
\hline 209 & $60 \cdot 9$ & $5 \cdot 37$ & & & & 5 & & SaSP \\
\hline 210 & $69 \cdot 3$ & $4 \cdot 70$ & 25 & & & 13 & 54 & \\
\hline 342 & $42 \cdot 5$ & $6 \cdot 44$ & 10 & & & & & OxSP \\
\hline 347 & $49 \cdot 2$ & $6 \cdot 05$ & 5 & & & & & OxSP \\
\hline 350 & $63 \cdot 8$ & $5 \cdot 79$ & 7 & & 6 & & & \\
\hline 354 & $78 \cdot 1$ & $5 \cdot 45$ & & & & & 7 & HSP \\
\hline 355 & $54 \cdot 7$ & $6 \cdot 39$ & 17 & & & & & OxSP \\
\hline 356 & $59 \cdot 0$ & $6 \cdot 39$ & 6 & & & & & OxSP \\
\hline 357 & $50 \cdot 3$ & $6 \cdot 12$ & & 8 & 19 & & & \\
\hline 358 & $28 \cdot 1$ & $6 \cdot 25$ & 5 & & 7 & & & \\
\hline 362 & $29 \cdot 2$ & $5 \cdot 91$ & & 7 & & & & ASP \\
\hline 370 & $43 \cdot 7$ & $4 \cdot 88$ & & & & & 5 & HSP \\
\hline 371 & $31 \cdot 2$ & $4 \cdot 87$ & & 16 & & & & ASP \\
\hline 501 & $47 \cdot 2$ & $4 \cdot 64$ & & 36 & & & & ASP \\
\hline
\end{tabular}


Table 3 (cont.)

\begin{tabular}{|c|c|c|c|c|c|c|c|c|}
\hline \multirow[t]{2}{*}{$\begin{array}{l}\text { Protein } \\
\text { ID }\end{array}$} & \multirow{2}{*}{$\begin{array}{l}\text { Mol. } \\
\text { mass } \\
(\mathrm{kDa})\end{array}$} & \multirow[t]{2}{*}{$\mathrm{pI}$} & \multicolumn{5}{|c|}{$\begin{array}{l}\text { Increase in synthesis under } \\
\text { stress condition* }\end{array}$} & \multirow[t]{2}{*}{$\begin{array}{c}\text { Stress } \\
\text { protein } †\end{array}$} \\
\hline & & & Oxid & Acid & Starved & Salt & Heat & \\
\hline 502 & $43 \cdot 5$ & $4 \cdot 63$ & & 21 & & & & ASP \\
\hline 503 & $41 \cdot 0$ & $4 \cdot 66$ & & 13 & & & & ASP \\
\hline 504 & $41 \cdot 9$ & $4 \cdot 73$ & & 8 & & & & ASP \\
\hline 506 & $24 \cdot 5$ & $4 \cdot 79$ & & 17 & & & & ASP \\
\hline $508 \mathrm{a}$ & $61 \cdot 4$ & $4 \cdot 76$ & & 11 & & 43 & & \\
\hline 509 & $59 \cdot 1$ & $4 \cdot 68$ & & 5 & & & & ASP \\
\hline 510 & $60 \cdot 5$ & $5 \cdot 94$ & & 43 & & & & ASP \\
\hline 511 & $29 \cdot 3$ & $5 \cdot 07$ & & 8 & & & & ASP \\
\hline 513 & $54 \cdot 7$ & $4 \cdot 74$ & & 7 & & & & ASP \\
\hline 514 & $47 \cdot 4$ & $4 \cdot 74$ & & 7 & & & & ASP \\
\hline
\end{tabular}

* Stress conditions: Oxid, $+2 \mathrm{mM} \mathrm{H}_{2} \mathrm{O}_{2}$; Acid, pH $7 \cdot 5$ to $5 \cdot 5$; Starved, 100 to $20 \% \mathrm{BM}$; Salt, $+0 \cdot 2 \mathrm{M}$ $\mathrm{NaCl}$; Heat, $37^{\circ} \mathrm{C}$ to $42^{\circ} \mathrm{C}$.

† Stress proteins: OxSP, oxidation-specific protein; ASP, acid-specific protein; SSP, starvation-specific protein; SaSP, salt-specific protein; HSP, heat-specific protein; GSP, general stress protein.

Table 4. Proteins downregulated fivefold or more in exponential-phase cells of S. mutans $\mathrm{H} 7$ under conditions of stress

Data obtained from the analysis of Fig. 2 and calculated as the IOD \% of the protein spot under the stress condition vs the same spot in the control.

\begin{tabular}{|c|c|c|c|c|c|c|c|c|}
\hline \multirow[t]{2}{*}{$\begin{array}{l}\text { Protein } \\
\text { ID }\end{array}$} & \multirow{2}{*}{$\begin{array}{l}\text { Mol } \\
\text { mass } \\
(\mathrm{kDa})\end{array}$} & \multirow[t]{2}{*}{ pI } & \multicolumn{5}{|c|}{$\begin{array}{l}\text { Decrease in synthesis under stress } \\
\text { condition" }\end{array}$} & \multirow[t]{2}{*}{ Stress protein $\rceil$} \\
\hline & & & Oxid & Acid & Starved & Salt & Heat & \\
\hline $1 \mathrm{a}$ & $83 \cdot 6$ & $5 \cdot 38$ & & 6 & & & 8 & \\
\hline $1 b$ & $87 \cdot 3$ & $5 \cdot 40$ & & & & & 5 & HSRP \\
\hline $1 \mathrm{c}$ & $87 \cdot 5$ & $5 \cdot 45$ & & & & & 5 & HSRP \\
\hline $1 d$ & $87 \cdot 3$ & $5 \cdot 35$ & & & & & 5 & HSRP \\
\hline $4 a$ & $40 \cdot 4$ & $5 \cdot 33$ & 5 & & & 9 & & \\
\hline 30 & $22 \cdot 9$ & $5 \cdot 83$ & & 6 & & & & ASRP \\
\hline 43 & $18 \cdot 3$ & $4 \cdot 90$ & & & & & 21 & HSRP \\
\hline 75 & $43 \cdot 7$ & $6 \cdot 14$ & & & & 6 & & SaSRP \\
\hline 83 & $21 \cdot 7$ & $5 \cdot 22$ & 43 & & & & & OxSRP \\
\hline 85 & $40 \cdot 7$ & $6 \cdot 39$ & & & & 6 & 6 & \\
\hline 99 & $35 \cdot 5$ & $6 \cdot 12$ & & & & 9 & 5 & \\
\hline $102 \mathrm{a}$ & $74 \cdot 3$ & $4 \cdot 70$ & & & 6 & & & SSRP \\
\hline 108 & $63 \cdot 5$ & $5 \cdot 22$ & & & & 29 & & SaSRP \\
\hline 112 & $42 \cdot 5$ & $5 \cdot 58$ & & & & 9 & & SaSRP \\
\hline 113 & $40 \cdot 5$ & $5 \cdot 39$ & & & & 5 & & SaSRP \\
\hline 164 & $42 \cdot 1$ & $6 \cdot 24$ & & & & & 6 & HSRP \\
\hline 174 & $48 \cdot 1$ & $5 \cdot 25$ & 6 & & & & & OxSRP \\
\hline 335 & $20 \cdot 4$ & $5 \cdot 25$ & & & & 5 & & SaSRP \\
\hline
\end{tabular}

*Stress conditions: Oxid, $+2 \mathrm{mM} \mathrm{H}_{2} \mathrm{O}_{2}$; Acid, pH 7.5 to 5.5; Starved, 100 to $20 \%$ BM; Salt, $+0 \cdot 2 \mathrm{M}$ $\mathrm{NaCl}$; Heat, $37^{\circ} \mathrm{C}$ to $42{ }^{\circ} \mathrm{C}$.

† Stress proteins: OxSRP, oxidation-specific repressed protein; ASRP, acid-specific repressed protein; SSRP, starvation-specific repressed protein; SaSRP, salt-specific repressed protein; HSRP, heatspecific repressed protein. 
regulated by individual nutrient components (Nyström, 1993; Spector \& Foster, 1993).

\section{ACKNOWLEDGEMENTS}

We would like to thank Elke Greif (Winnipeg) and Ulla-Britt Larsson (Malmö) for their excellent technical assistance. This study was supported by grants to I.R.H. from the Medical Research Council of Canada (MT-3546) and to G. S. from the Medical Research Council of Sweden (K97-24X-12266-01).

\section{REFERENCES}

Belli, W. A. \& Marquis, R. E. (1991). Adaptation of Streptococcus mutans and Enterococcus hirae to acid stress in continuous culture. Appl Environ Microbiol 57, 1134-1138.

Bender, G. R., Sutton, S. C. V. \& Marquis, R. E. (1986). Acid tolerance, proton permeabilities, and membrane ATPase of oral streptococci. Infect Immun 53, 331-338.

Bernhardt, J., Völker, U., Völker, A., Antelmann, H., Schmid, R., Mach, H. \& Hecker, M. (1997). Specific and general stress proteins in Bacillus subtilis - a two-dimensional electrophoretic study. Microbiology 143, 999-1017.

Bloomberg, A. (1997). Osmoresponsive proteins and functional assessment strategies in Saccharomyces cerevisiae. Electrophoresis 18, 1429-1440.

Bowden, G. H. W. (1991). Which bacteria are cariogenic in humans? In Dental Caries, vol. 1, Markers of High and Low Risk Groups and Individuals, pp. 266-286. Edited by N. M. Johnson. Cambridge: Cambridge University Press.

Bradford, M. M. (1976). A rapid and sensitive method for the quantitation of microgram quantities of protein utilizing the principle of protein-dye binding. Anal Biochem 72, 248-354.

Carlsson, J. \& Hamilton, I. R. (1996). Differential toxic effects of lactate and acetate on the metabolism of Streptococcus mutans and Streptococcus sanguis. Oral Microbiol Immunol 11, 412-419.

Dashper, S. G. \& Reynolds, E. C. (1992). $\mathrm{pH}$ regulation by Streptococcus mutans. J Dent Res 71, 1159-1165.

Dashper, S. G. \& Reynolds, E. C. (1996). Lactic acid excretion by Streptococcus mutans. Microbiology 142, 33-39.

Fey, S. J., Nawrocki, A., Larsen, M. R., Görg, A., Roepstorff, P., Skews, G. N., Williams, R. \& Mose Larsen, P. (1997). Proteome analysis of Saccharomyces cerevisiae: a methodological outline. Electrophoresis 18, 1361-1372.

Foster, J. W. (1993). The acid tolerance response of Salmonella typhimurium involves transient synthesis of key acid shock proteins. J Bacteriol 175, 1981-1987.

Gale, E. F. \& Epps, H. M. R. (1942). The effect of pH of the medium during growth on the enzymic activities of bacteria (Escherichia coli and Micrococcus lysodeikticus) and the biological significance of the changes produced. Biochem J 36, 600-619.

Hamilton, I. R. (1986). Growth, metabolism and acid production by Streptococcus mutans. In Molecular Microbiology and Immunobiology of Streptococcus mutans, pp. 255-262S. Edited by S. Hamada, S. U. Michalek, H. Kiyono, L. Menaker \& J. R. McGhee. Amsterdam: Elsevier.

Hamilton, I. R. (1987). Effect of changing environment on sugar transport and metabolism by oral bacteria. In Sugar Transport and Metabolism by Gram-positive Bacteria, pp. 94-133. Edited by J. Reizer \& A. Peterkofsky. Chichester: Ellis Horwood.

Hamilton, I. R. (1990). Maintenance of proton motive force by
Streptococcus mutans and Streptococcus sobrinus during growth in continuous culture. Oral Microbiol Immunol 5, 280-287.

Hamilton, I. R. \& Buckley, N. D. (1991). Adaptation by Streptococcus mutans to acid tolerance. Oral Microbiol Immunol 6, 65-71.

Hamilton, I. R. \& Ellwood, D. C. (1978). Effects of fluoride on carbohydrate metabolism by washed cells of Streptococcus mutans grown at various $\mathrm{pH}$ values in a chemostat. Infect Immun 19, 434-442.

Hamilton, I. R. \& Svensäter, G. (1998). Acid-regulated proteins induced by Streptococcus mutans and other oral bacteria during acid shock. Oral Microbiol Immunol 13, 292-300.

Hartke, A., Bouche, S., Gansel, X., Boutibonnes, P. \& Auffray, Y. (1994). Starvation-induced stress resistance in Lactobacillus lactis subsp. lactis IL1403. Appl Environ Microbiol 60, 3474-3478.

Hartke, A., Bouche, S., Gansel, X., Boutibonnes, P. \& Auffray, Y. (1995). UV-inducible proteins and UV-induced cross protection against acid, ethanol, $\mathrm{H}_{2} \mathrm{O}_{2}$ or heat treatments of Lactobacillus lactis subsp. lactis. Arch Microbiol 163, 329-336.

Hartke, A., Bouche, S., Giard, J.-C., Benachour, A., Boutibonnes, P. \& Auffray, Y. (1996). The lactic acid stress response of Lactobacillus lactis subsp. lactis. Curr Microbiol 33, 194-199.

Hecker, M., Schumann, W. \& Völker, U. (1996). Heat-shock and general stress response in Bacillus subtilis. Mol Microbiol 19, 417-428.

Hersh, B. M., Farooq, F. T., Barstad, D. N., Blankenhorn, D. L \& Slonczewski, J. L. (1996). A glutamate-dependent acid resistance gene in Escherichia coli. J Bacteriol 178, 3978-3981.

van Houte, J., Lopman, J. \& Kent, R. (1996). The final pH of bacteria comprising the predominant flora of sound and carious human root and enamel surfaces. J Dent Res 75, 1008-1014.

Imfeld, T. \& Lutz, F. (1980). Intraplaque acid formation assessed in vivo in children and young adults. Pediatr Dent 2, 87-93.

Jensen, M. E., Polansky, P. J. \& Schachtele, C. F. (1982). Plaque sampling and telemetry for monitoring acid production on human buccal tooth surfaces. Arch Oral Biol 27, 21-31.

Kilstrup, M., Jacobsen, S., Hammer, K. \& Vogensen, F. K. (1997). Induction of heat-shock proteins DnaK, GroEL, and GroES by salt stress in Lactococcus lactis. Appl Environ Microbiol 63, $1826-1837$.

Laemmli, U. K. (1970). Cleavage of structural proteins during the assembly of the head of bacteriophage T4. Nature 227, 680-685.

Leyer, G. J. \& Johnson, E. A. (1993). Acid adaptation induces cross-protection against environmental stresses in Salmonella typhimurium. Appl Environ Microbiol 59, 1842-1847.

Nyström, T. (1993). Global systems approach to the physiology of the starved cell. In Starvation in Bacteria, pp. 129-150. Edited by S. Kjelleberg. New York: Plenum.

Padan, E., Zilberstein, D. \& Schuldiner, S. (1981). pH homeostasis in bacteria. Biochim Biophys Acta 650, 151-166.

Rallu, F., Gruss, A. \& Maquin, E. (1996). Lactobacillus lactis and stress. Antonie Leeuwenhoek 70, 243-251.

Sansone, C., van Houte, J., Joshipura, K., Kent, R. \& Margolis, H. C. (1993). The association of mutans streptococci and nonmutans streptococci capable of acidogenesis at a low $\mathrm{pH}$ with dental caries on enamel and root surfaces. J Dent Res 72, 508-516.

Spector, M. P. \& Foster, J. W. (1993). Starvation-stress response (SSR) of Salmonella typhimurium. In Starvation in Bacteria, pp. 201-224. Edited by S. Kjelleberg. New York: Plenum.

Stephan, R. M. (1944). Intra-oral hydrogen-ion concentration associated with dental caries activity. J Dent Res 23, 257-266. 
Sutton, S. V. W. \& Marquis, R. E. (1987). Membrane-associated and solubilized ATPases of Streptococcus mutans and Streptococcus sanguis. J Dent Res 66, 1095-1098.

Svensäter, G., Larsson, U.-B., Greif, E. C. G., Cvitkovitch, D. G. \& Hamilton, I. R. (1997). Acid tolerance response and survival by oral bacteria. Oral Microbiol Immunol 12, 266-273.

Tao, L., MacAlister, T. J. \& Tanzer, J. M. (1993). Transformation efficiency of EMS-induced mutants of Streptococcus mutans of altered cell shape. J Dent Res 72, 1032-1039.

VanBogelen, R. A., Kelly, P. M. \& Neidhardt, F. C. (1990). Gene- protein database of Escherichia coli K-12: edition 3. Electrophoresis 11, 1131-1166.

Yamada, T., Igarashi, K. \& Mitsutomi, M. (1980). Evaluation of cariogenicity of glycosylsucrose by a new method of measuring $\mathrm{pH}$ under human dental plaque in situ. J Dent Res 59, 2157-2162.

Yura, T., Nagai, H. \& Mori, H. (1993). Regulation of heat-shock response in bacteria. Annu Rev Microbiol 47, 321-350.

Received 20 May 1999; revised 6 September 1999; accepted 24 September 1999. 